\title{
SISTEM PAKAR DIAGNOSA PENYAKIT KUCING FELINE VIRUS MENGGUNAKAN METODE CERTAINTY FACTOR BERBASIS WEB
}

\author{
B. Yoriko Tri Astono ${ }^{1}$, Muhammad Syafri Febrian ${ }^{2}$, Wegig Purba Laksana ${ }^{3}$, \\ Rafael Inggil Laveri ${ }^{4}$ \\ 1,2,3,4 Program Studi Teknik Informatika, Universitas Amikom Purwokerto \\ Jl. Pol. Soemarto, Karangjambu, Purwanegara, Kec. Purwokerto Utara, Kabupaten Banyumas, Jawa Tengah 53127, \\ telp/fax: (0281) 623321/ (0281) 623196 \\ ${ }^{1}$ rafaellaveri28@gmail.com
}

Abstrak: Kucing merupakan hewan peliharaan yang banyak disukai oleh semua kalangan,saking banyaknya hampir diseluruh pelosok tempat terdapat kucing, karna kepopulerannya dikalangan masa, tidak kaget kalo banyak yang memilihara hewan ini. Namun kepopulerannya dan banyaknya orang memelihara hewan ini tidak diimbangi dengan pemeliharaanya, cara merawat, dan dokter hewan yang belum semua tempat ada. Oleh karena itu kami berinisiatif untuk membantu para dokter,dan semua orang yang memerlukanya. untuk mengembangkan aplikasisistem pakar untuk mendiagnosis penyakit Feline virus yang dialami pada kucing. Sistem pakar ini akan dibuat menggunakan bahasa pemrograman PHP dengan metode Certainty Factor dan sebagai penampung datanya akan menggunakan Database MySQL. Sistem Pakar yang kami buat akan menghasilkan output diagnosa penyakit yang berdasarkan user yang menginputkan Sistem pakar juga berguna sebagai alat untuk menyimpan pengetahuan seorang pakar khususnya pakar penyakit kucing. Dengan adanya sistem pakar ini diharapkan masyarakat dapat memperoleh informasi mengenai penyakit yang dialami kucing.

Kata Kunci: Sistem Pakar, Certainty Factor, Penyakit Feline Virus, Kucing.

Abstract: Cats are pets that are protected by all people, who spend a lot of money in a cat's place, because of their popularity among the time, not surprised because many who choose these animals. However, the popularity and number of people raising animals is not balanced with their care, how to care for them, and veterinarians who do not have all the places. Therefore we took the initiative to help doctors, and all those who are requested. to develop expert system applications to diagnose Feline Virus that is experienced in cats. This expert system will be created using the PHP programming language with the Certainty Factor method and as a data collector it will use the MySQL Database. The Expert System that we create will produce an output of a disease diagnosis based on the user who input the Expert system is also useful to save knowledge of experts in cat disease experts. With the existence of this expert system, it is expected that the public will know the information about the diseases that cats experience.

Keywords: Expert System, Certainty Factor, Feline Disease Virus, Cats

\section{Pendahuluan}

Kucing adalah salah satu hewan peliharaan yang paling banyak dipelihara oleh manusia. Manusia sebagai pemilik kucing diharapkan dapat mengetahui cara pencegahan maupun cara perawatan berbagai macam penyakit pada kucing agar tidak mengganggu kesehatan lingkungan dan pemiliknya.

Kucing adalah salah satu makluk hidup yang tidak luput dari penyakit ,Pada tubuh kucing terdapat antibody yang melindungi tubuh dengan dari virus gangguan lingkungan luar. Kondisi ini dapat menjadi representasi kesehatan kucing secara umum serta dapat dijadikan sebagai pertanda terhadap adanya suatu penyakit dalam tubuh kucing. Penyakit Feline virus salah satu jenis penyakit yang ada pada kucing, terkadang 
Jurnal Pseudocode, Volume V Nomor 2, September 2018, ISSN 2355-5920, e-ISSN 2655-1845 www.ejournal.unib.ac.id/index.php/pseudocode

kucing yang terkena penyakit Feline virus memiliki nafsu makan yang kurang, demam, Radang Mata ,Badanya terlihat Lemas , Bersin, Diare dan Hidungnya Berlendir .

Namun bila hal tersebut dibiarkan terus menerus, maka akan berakibat fatal bahkan dapat menyebabkan kematian, Pemilik kucing terkadang baru menyadari saat kucing peliharaannya mengalami perubahan secara signifikan seperti ciri-ciri yang tertera di atas. Kesehatan kucing sangatlah penting hal ini tidak terlepas dari peran klinik rumah sakit hewan yang sangat dibutuhkan untuk melakukan tindakan medis pada hewan peliharaan. Akan tetapi keterbatasan seorang dokter hewan dalam melakukan diagnosis penyakit kucing, maka diperlukan sebuah sistem yang membantu para dokter hewan dalam menangani kasus penyakit kucing.

Beberapa permasalah dalam perencanaan pengembangan sistem yang akan dibangun yaitu minimnya pengetahuan dari pemilik kucing mengenai penyakit kulit kucing, keterbatasan para pakar khususnya spesialis penyakit pada kucing yang dapat membantu memberikan informasi penyakit dan solusi penanganannya Berdasarkan latar belakang dan identifikasi masalah diatas, dapat ditarik sebuah rumusan masalah, yaitu perlunya dibuat sistem pakar agar dapat membantu masyarakat, khususnya para pemilik kucing untuk mendapatkan informasi mengenai penyakit kulit, gejala-gejala serta jenis penyakit yang diderita.

Sistem pakar yang dibuat oleh penulis adalah sebuah sistem pakar berbasis web, yang mana dengan sistem pakar berbasis website dapat membantu para pemilik kucing untuk mengetahui penyakit yang ada pada kucing mereka hanya dengan membuka website saja tanpa harus pergi ke klinik hewan.

Berdasarkan permasalahan yang telah penulis uraikan, maka dapat diidentifikasikan permasalahan yang terjadi adala kurangnya pengetahuan yang dimiliki para pemilik kucing mengenai penyakit pada kucing, keterbatasan para pakar khususnya spesialis penyakit kucing yang dapat membantu memberikan informasi penyakit beserta alternatif penanganannya. Maksud dari penelitian ini adalah membuat suatu bentuk perancangan sistem pakar. Sistem pakar membantu para pakar untuk menyimpan kepakarannya dan sistem ini akan bekerja secara konsisten untuk membantu dalam mengatasi suatu masalah [1]. Sistem pakar memberikan nilai tambah pada teknologi untuk membantu dalam menangani era informasi yang semakin canggih [1].

Tujuan penelitian ini adalah: mendiagnosa penyakit kucing sebagai langkah awal untuk menerapkan buatan dalam dunia medis, kecerdasan merancang dan mengaplikasikan sistem pakar yang mampu mendiagnosis penyakit kulit kucing dengan memperhatikan aturan, metode dan desain sistem sehingga dapat terbantu dengan adanya sistem pakar ini, memberikan alternatif pemecahan masalah mengenai bagaimana cara menanggulangi penyakit kucing.

\section{LANDASAN KEPUSTAKAAN}

\section{A. Penyakit Kucing}

Pada sistem ini hanya dapat mengidentifikasi beberapa macam penyakit kucing saja. Berikut merupakan macam-macam penyakit kucing yang diidentifikasi: Feline Panleukopenia Virus, Feline Calici virus, Feline Rhinotracheitis Virus, 
Jurnal Pseudocode, Volume V Nomor 2, September 2018, ISSN 2355-5920, e-ISSN 2655-1845 www.ejournal.unib.ac.id/index.php/pseudocode

Feline Immunodefisiensi Virus, Feline Leukemia Virus.

\section{B. Sistem Pakar}

Sistem pakar adalah sistem cerdas berbasis komputer digunakan dalam penyelesaian masalah yang hanya bisa dilakukan oleh ahli/pakar pada suatu bidang. Dengan sistem ini masyarakat umum dapat melakukan perhitungan layaknya seorang pakar [2]. Terdapat dua bagian penting dari sistem pakar meliputi lingkungan konsultasi dan lingkungan pengembang. Lingkungan pengembang digunakan oleh pengembang sistem untuk membangun komponen dan memperkenalkan pengetahuan ke dalam basis pengetahuan. Untuk linkungan konsultasi berguna untuk melakukan konsultasi sehingga memperoleh penegetahuan dari sistem pakar layaknya dari seorang pakar [2].

\section{Certainty Factor Certainty theory}

Menggunakan suatu nilai yang disebut Certainty Factor (CF) untuk mengasumsikan derajat keyakinan seorang pakar terhadap suatu data [2]. Ditunjukkan Formula Certainty Factor oleh Giarattano dan Riley, 1994 menggunakan persamaan (4).

$$
\mathrm{CF}(\mathrm{H}, \mathrm{E})=\mathrm{MB}(\mathrm{H}, \mathrm{E})-\mathrm{MD}(\mathrm{H}, \mathrm{E})
$$

Keterangan:

$\mathrm{CF}(\mathrm{H}, \mathrm{E})=$ Certainty Factor dari hipotesis $\mathrm{H}$ yang dipengaruhi oleh gejala (evidence) E. Besarnya CF berkisar antara -1 sampai 1 . Nilai 1 menunjukkan kepercayaan mutlak sedangkan nilai -1 menunjukkan ketidakpercayaan mutlak.

MB $(\mathrm{H}, \mathrm{E})=$ ukuran kenaikan kepercayaan (measure of increased belief) terhadap hipotesis $\mathrm{H}$ yang dipengaruhi oleh gejala $\mathrm{E}$.
MD $(\mathrm{H}, \mathrm{E})=$ ukuran kenaikan ketidakpercayaan (measure of increased disbelief) terhadap hipotesis $\mathrm{H}$ yang dipengaruhi oleh gejala $\mathrm{E}$.

\section{BAHAN DAN METODE}

\section{A. Teknik Pengumpulan Data}

Untuk memperoleh informasi atau data sebagai bahan pokok dalam penulisan jurnal ini, maka penulis melakukan langkah-langkah untuk mendapatkan data yaitu dengan cara:

\section{Observasi}

Pada tahapan Observasi kami melakukan pengamatan dengan mendatangi Pet Shop dan klinik sejenisnya.

2. Wawancara

Dalam tahapan wawancara, kami mewawancarai dokter hewan yang ada di Pet Shop dan klinik sejenisnya.

3. Studi Pustaka

Untuk tahapan ini kami mencari sumber terkait bahan yang akan kami cantumkan di program kami melalui e-book dan journal.

\section{B. Metode Pengembangan Sistem Pakar}

Sistem pakar yang baik harus memiliki ciriciri sebagai berikut (Azhar, Sari, \& Zulita, 2014)

a. Memiliki fasilitas informasi yang handal.

b. Mudah dimodifikasi.

c. Dapat digunakan dalam berbagai komputer.

d. Memiliki kemampuan untuk belajar beradaptasi.

Pada penelitian ini kami menggunakan metode Certainty Factor untuk pembuatan sistem pakar diagnosa penyakit kucing. Certainty Factor (Faktor Kepastian) adalah menyatakan kepercayaan dalam sebuah kasus (atau fakta atau hipotesis) berdasarkan bukti atau penilaian pakar. Certainty factor menggunakan suatu nilai untuk mengasumsi derajat keyakinan seorang pakar 
Jurnal Pseudocode, Volume V Nomor 2, September 2018, ISSN 2355-5920, e-ISSN 2655-1845 www.ejournal.unib.ac.id/index.php/pseudocode

terhadap suatu data. Berikut adalah rancangan algoritme pada sistem pakar yang penulis buat:

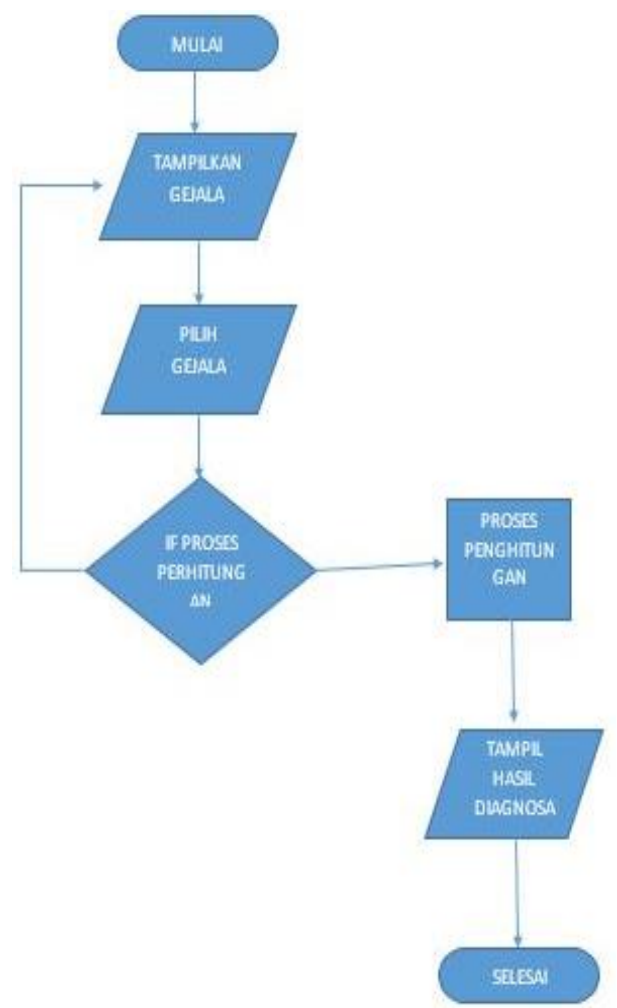

Gambar 1. Rancangan algoritme

\section{ANALISIS KEBUTUHAN}

\section{A. Gambaran Umum Sistem}

Sistem pakar diagnosis penyakit kucing menggunakan metode Certainty Factor merupakan sistem yang dapat melakukan proses diagnosis penyakit terhadap seekor kucing berdasarkan gejala-gejala masukan dari pengguna aplikasi. Sistem ini dibangun dengan berbasis web yang dikembangkan menggunakan html dengan bahasa pemrograman php. Pada sistem ini tersedia 3 tampilan, yaitu tampilan gejala, tampilan proses penghitungan, tampilan hasil penghitungan. Tampilan gejala berisi mengenai gejala yang terdapat pada kucing, pada tampilan ini pengguna melakukan proses diagnosis dengan memasukkan beberapa gejala pada checkbox yang tersedia dan nantinya hasilnya akan dihitung pada halaman proses penghitungan. Tampilan proses penghitungan berisi tentang bagaimana cara penghitungan terhadap gejala yang di timbulkan dan menjadi kumpulan nilai untuk menentukan penyakit yang didapat. Yang terakhir adalah tampilan hasil penghitungan, tampilan ini berisi mengenai informasi tentang hasil dari gejalan yang sudah diproses.

\section{B. Identitas User}

Tahap ini ditujukan untuk melakukan identifikasi user yang berinteraksi dengan sistem pakar. User apa saja yang terlibat dalam sistem pakar beserta proses apa saja yang dapat dilakukan oleh user berikut pada Tabel 1.

Tabel 1. Identifikasi User

\begin{tabular}{|l|l|}
\hline \multicolumn{1}{|c|}{ User } & \multicolumn{1}{|c|}{ Deskripsi } \\
\hline Pengguna & $\begin{array}{l}\text { User dapat melakukan pengisian } \\
\text { pada gejala, melihat proses } \\
\text { penghitungan, dan melihat hasil } \\
\text { diagnosis. }\end{array}$ \\
\hline
\end{tabular}

\section{Kebutuhan Fungsional}

Pada bagian analisis kebutuhan fungsional akan di tampilkan daftar kebutuhan kebutuhan yang diperlukan untuk membuat aplikasi sistem pakar diagnosis penyakit kucing menggunakan metode certainty factor. Kebutuhan fungsional ditunjukkan pada pada Tabel 2.

Tabel 2. Kebutuhan Fungsional

\begin{tabular}{|c|c|c|}
\hline No & Nama Fungsi & Deskripsi Kebutuhan \\
\hline 1 & $\begin{array}{l}\text { Menampilkan } \\
\text { gejala }\end{array}$ & $\begin{array}{l}\text { Aplikasi harus menampilkan } \\
\text { keterangan dari masing-masing } \\
\text { gejala dalam menu gejala }\end{array}$ \\
\hline 2 & $\begin{array}{l}\text { Menentukan } \\
\text { gejala }\end{array}$ & $\begin{array}{l}\text { Aplikasi harus menyediakan } \\
\text { cekbox untuk digunakan } \\
\text { pengguna sebagai masukan } \\
\text { gejalagejala penyakit } \\
\text { untuk diagnosis }\end{array}$ \\
\hline
\end{tabular}


Jurnal Pseudocode, Volume V Nomor 2, September 2018, ISSN 2355-5920, e-ISSN 2655-1845 www.ejournal.unib.ac.id/index.php/pseudocode

\begin{tabular}{|l|l|l|}
\hline No & Nama Fungsi & \multicolumn{1}{c|}{ Deskripsi Kebutuhan } \\
\hline 3 & $\begin{array}{l}\text { Menampilkan } \\
\text { proses } \\
\text { penghitungan }\end{array}$ & $\begin{array}{l}\text { Aplikasi harus menampilkan } \\
\text { perhitungan tentang nilai CF untuk } \\
\text { melihat berapa tingginya nilai } \\
\text { perhitungan }\end{array}$ \\
\hline 4 & $\begin{array}{l}\text { Menampilkan } \\
\text { hasil } \\
\text { penghitungan }\end{array}$ & $\begin{array}{l}\text { Aplikasi harus menampilkan hasil } \\
\text { dari perhitungan dan } \\
\text { menampilkan hasil dari gejala } \\
\text { dan penyakitnya }\end{array}$ \\
\hline
\end{tabular}

\section{Usecase Diagram}

Use case diagram merupakan gambaran pada sistem yang menjelaskan interaksi user terhadap sistem yang akan dibuat. Use case diagram sangat penting untuk menjadi panduan bagi user maupun bagi developer untuk dalam proses pengembangan sistem. Di dalam use case akan menjelaskan secara singkat bagaimana hubungan anatara usecase, user, dan juga sistem. Berikut adalah Use Case Diagram dari sistem, pada Gambar 2.
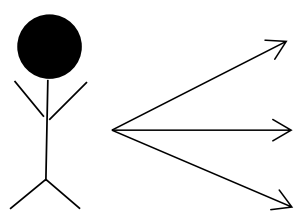

\section{Memilih Gejala}

Proses Penghitungan

Hasil Penghitungan

Gambar 2. Use case diagram

Gambar 2 merupakan model Use Case Diagram yang telah dibuat terdapat 1 (satu) user dan 3 (tiga) use case yaitu melihat gejala, proses hitung, dan hasil.

\section{PERANCANGAN DAN IMPLEMENTASI SISTEM}

\section{A. Basis Pengetahuan}

Basis pengetahuan merupakan kumpulan suatu informasi atau data yang diperoleh dari pakar untuk memecahkan suatu permasalahan terhadap suatu bidang tertentu. Basis pengetahuan bersifat dinamis, dapat berubah sewaktu-waktu karena pengetahuan dapat berkembang. Basis pengetahuan merupakan inti dari sistem pakar karena basis pengetahuan dijadikan sebagai acuan dalam perhitungan sistem pakar.

Basis pengetahuan mencakup dua elemen dasar, yaitu fakta dan aturan (mengarahkan pengguna untuk memecahkan masalah khusus dalam domain tertentu). Berikut merupakan sekumpulan informasi atau data yang digunakan pada penelitian ini, jenis penyakit kucing ditunjukkan pada Tabel 3, gejala penyakit kucing ditunjukkan pada Tabel 4 dan aturan diagnosis penyakit kucing ditunjukkan pada Tabel 5.

Tabel 3. Jenis Penyakit Kucing

\begin{tabular}{|c|l|}
\hline Kode Penyakit & \multicolumn{1}{|c|}{ Nama Penyakit } \\
\hline A & Feline Panleukopenia Virus \\
\hline B & Feline Calici virus \\
\hline D & Feline Rhinotracheitis Virus \\
\hline F & Feline Immunodefisiensi Virus \\
\hline G & Feline Leukemia Virus \\
\hline
\end{tabular}

Tabel 4. Gejala Penyakit Kucing

\begin{tabular}{|c|l|}
\hline Kode Gejala & \multicolumn{1}{c|}{ Gejala } \\
\hline 1 & Nafsu Makan Hilang \\
\hline 2 & Demam \\
\hline 3 & Radang Mata \\
\hline 4 & Badan Lemas \\
\hline 5 & Bersin \\
\hline 6 & Diare \\
\hline 7 & Hidung Berlendir \\
\hline
\end{tabular}

Tabel 5. Aturan Diagnosis Penyakit kucing

\begin{tabular}{|c|c|l|}
\hline Aturan & Penyakit & \multicolumn{1}{|c|}{ Gejala } \\
\hline R1 & A & 2,6 \\
\hline R2 & B & $1,3,4$ \\
\hline R3 & D & $7,6,1$ \\
\hline R4 & F & $1,2,3,4,5,6,7$ \\
\hline R5 & G & 6 \\
\hline
\end{tabular}


Jurnal Pseudocode, Volume V Nomor 2, September 2018, ISSN 2355-5920, e-ISSN 2655-1845 www.ejournal.unib.ac.id/index.php/pseudocode

\section{B. Langkah-langkah Perhitungan Certainty}

Factor

1. Penyakit yang akan dihitung nilai kepastiannya merupakan penyakit dari hasil diagnosis. Pada perhitungan ini nilai CFpakar dikalikan dengan CFuser.

2. Setelah nilai CF dihitung, maka selanjutnya yaitu menghitung nilai CFcombine. Perhitungan CFcombine menggunakan nilai $\mathrm{CF}$ yang diperoleh dari CFpakar*CFuser, dimana nilai CF dianggap sebagai nilai CF1 dan CF2. Setiap kali eksekusi hanya menggunakan dua buah data saja (CF1 dan $\mathrm{CF} 2$ ). Nilai tersebut digunakan untuk memberikan bobot pada setiap aturan yang ada.

\section{Rancangan User Interface}

User interface digunakan untuk memberika gambaran tentang bentuk tampilan dari aplikasi yang digunakan user.

\section{Tampilan Menu Utama User}

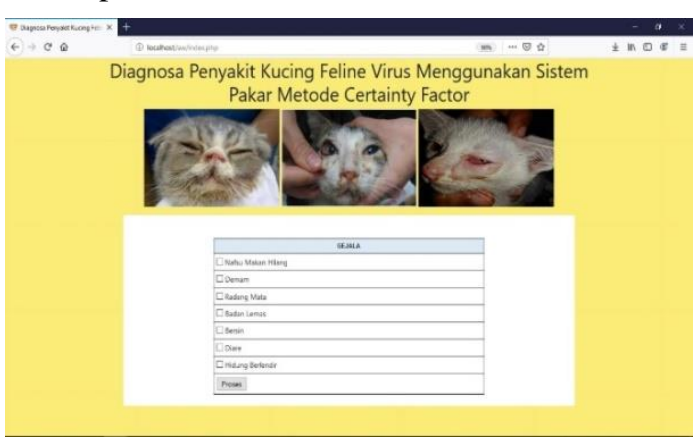

2. Tampilan Proses Penghitungan

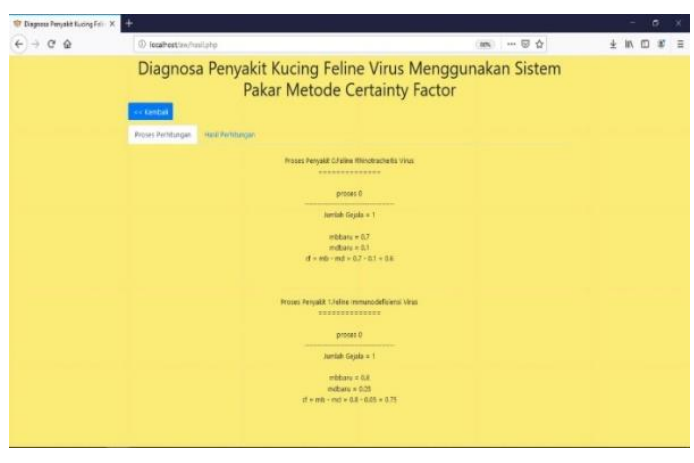

\section{Tampilan Hasil Diagnosis}

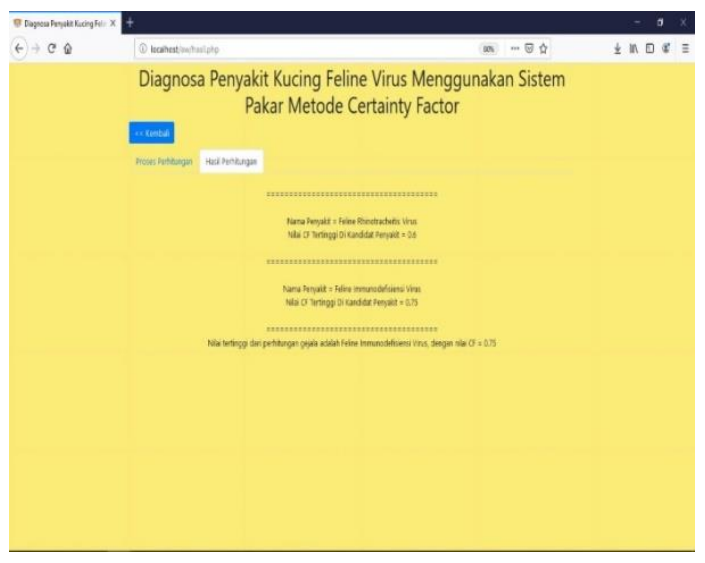

Selanjutnya, prosedur pengujian validasi dilakukan dengan pengujian blackbox. Pengujian diawali dengan mendefinisikan kebutuhan fungsional yang akan diuji. Setelah itu, hasil yang diharapkan akan dibandingkan dengan hasil yang didapatkan setelah melalui tahap-tahap pengujian yang telah ditentukan sebelumnya. Hasil pengujian terhadap kebutuhan fungsional memilih kode gejala, ditunjukkan pada Tabel 6.

Tabel 6. Kasus Uji Memilih Kode Gejala

\begin{tabular}{|l|l|}
\hline \multicolumn{1}{|c|}{ Nama Kasus Uji } & Memilih kode gejala \\
\hline Tujuan Pengujian & $\begin{array}{l}\text { Untuk memastikan system dapat } \\
\text { menampilkan checkbox kode } \\
\text { kode gejala dan sistem dapat } \\
\text { melakukan diagnosis } \\
\text { berdasarkan } \\
\text { masukan pengguna }\end{array}$ \\
\hline Prosedur Pengujian & $\begin{array}{l}\text { 1. Sistem dijalankan } \\
2 . \quad \text { Memilih menu diagnosis } \\
3 . \quad \text { Memilih kode gejala }\end{array}$ \\
\hline Hasil yang diharapkan & $\begin{array}{l}\text { Dapat menampilkan checkbox } \\
\text { kode-kode gejala dan sistem } \\
\text { dapat melakukan diagnosis } \\
\text { berdasarkan masukan } \\
\text { pengguna }\end{array}$ \\
\hline Hasil yang didapatkan & $\begin{array}{l}\text { Sistem menampilkan checkbox } \\
\text { kode-kode gejala dan } \\
\text { dapat melakukan diagnosis } \\
\text { berdasarkan masukan } \\
\text { pengguna }\end{array}$ \\
\hline Valid validasi & \\
\hline
\end{tabular}


Jurnal Pseudocode, Volume V Nomor 2, September 2018, ISSN 2355-5920, e-ISSN 2655-1845 www.ejournal.unib.ac.id/index.php/pseudocode

Berdasarkan prosedur pengujian yang telah dijalankan, maka dapat disimpulkan bahwa sistem pakar diagnosis penyakit kucing telah sesuai dengan seluruh kebutuhan fungsional yang telah ditentukan.

\section{KESIMPULAN}

Berdasarkan hasil perancangan dan pengujian yang sudah dilakukan pada sistem pakar pakar diagnosis penyakit kucing menggunakan Certainty Factor berbasis Web dapat diambil kesimpulan sebagai berikut:

1. Sistem Pakar Diagnosis Penyakit Kucing Menggunakan Metode Certainty Factor Berbasis Web, sistem ini dibangun dengan berbasis Web. Untuk metode Certanity Factor menggunakan gejala penyakit yang diberikan nilai kepercayaan. Sistem dapat mendiagnosis penyakit kucing dengan gejala yang digunakan sebanyak 7 butir dan jenis penyakit kucing sebanyak 5 butir berdasarkan hasil wawancara dengan pakar.
2. Terdapat 1 tahapan pengujian yang merupakan kelanjutan dari sistem ini sebagai syarat memenuhi kebutuhan pembuatan sistem.

Hasil pengujian validasi (blackbox) Sistem Pakar Diagnosis Penyakit Kucing Menggunakan Certainty Factor Berbasis Web dikarenakan pada semua kasus uji yang sudah dilakukan, secara keseluruhan dapat berfungsi dengan baik, maka tingkat persentase kesesuaian validasi sebesar $100 \%$.

\section{REFERENSI}

1. Nurajizah, Siti, and Maulana Saputra. "Sistem Pakar Berbasis Android Untuk Diagnosa Penyakit Kulit Kucing Dengan Metode Forward Chaining." Jurnal Pilar Nusa Mandiri 14.1 (2018): 7-14..

2. Nugraha, A. A. S., Hidayat, N. and Fanani, L. (2018) 'Sistem Pakar Diagnosis Penyakit Kucing Menggunakan Metode Naive Bayes - Certainty Factor Berbasis Android', Jurnal Pengembangan Teknologi Informasi dan Ilmu Komputer, 2(2), pp. 650-658. 